\title{
Two new and disparate fossil bee flies (Bombyliidae: Anthracinae) from the Americas and reassessment of Anthrax dentoni Lewis, 1969
}

\author{
Dale E. Greenwalt, Jonathan G. Wingerath, and Neal L. Evenhuis
}

\begin{abstract}
In this study, two new species of anthracine bee flies are described and one previously described species is reassessed. Anthrax succini Greenwalt and Evenhuis sp. nov. is the first of the very speciose genus Anthrax and only the second bombyliid to be described from Dominican amber. The previously described Anthrax dentoni Lewis, 1969 was re-examined and reassigned to Anthracinae incertae sedis due to lack of morphological detail required for generic assignment. Eoanomala melas Greenwalt and Evenhuis gen. and sp. nov. is described from the Middle Eocene oil shales of the Kishenehn Formation. Eoanomala melas contains a number of character states that are not found together in any extant genera and, although it may fit within the tribe Villini, it does not appear to be closely related to the extant constituents of that clade.
\end{abstract}

Dale E. Greenwalt. Department of Paleobiology, National Museum of Natural History MRC 121, Smithsonian Institution, 10th \& Constitution Ave. NW, Washington, D.C., 20013-7012, USA;

GreenwaltD@si.edu

Jonathan G. Wingerath. Department of Paleobiology, National Museum of Natural History MRC 121, Smithsonian Institution, 10th \& Constitution Ave. NW, Washington, D.C., 20013-7012, USA; WINGERAT@si.edu

Neal L. Evenhuis. Department of Natural Science, Bishop Museum, 1525 Bernice Street, Honolulu, Hawaii 96817-2704, USA; neale@bishopmuseum.org

Keywords: Bombyliidae; Anthrax; Dominican amber; Kishenehn Formation; new species; new genus

Submission: 24 June 2015. Acceptance: 6 October 2015

\section{INTRODUCTION}

Bee flies (Diptera: Bombyliidae) constitute a large and diverse family of 15 different extant subfamilies, more than 230 genera and nearly 5,000 species that, as adults, feed on nectar and/or pollen (females are obligate pollen feeders) and are found in all continents except Antarctica (Evenhuis and Greathead, 2003; Pape et al., 2011). Adult bombyliids are important pollinators and many have evolved a long proboscis to facilitate nectar feeding. While there is uncertainty about some of the supergeneric relationships among species of this clade, Mythicomyiidae (previously Mythicomyiinae) has been shown to be basal to all Bombyliidae, and the molecular data of Trautwein et al. (2011) place the subfamily Heterotropinae basal to Mythicomyiidae. 
All bombyliids, except Heterotropinae, are parasitoids that exhibit hypermetamorphosis, a phenomenon in which the first larval instar, or planidium, is sclerotized and mobile with legs and eyes. The planidium's function is to locate and enter a host, usually the larva of a holometabolous insect. Subsequent ecdysis produces a larval morphology optimized for feeding within its host. The success and diversity of the bombyliids is thought to be based, in part, on avoidance of direct competition with the many other parasitoids that lay their eggs directly on or in larval hosts (Wedmann and Yeates, 2008). Many bombyliid females simply scatter their eggs near potential hosts (e.g., in tunnels leading to nesting chambers); the planidia are responsible for host location. A major evolutionary advance in this behavior occurred with the development of the "sand chamber", a structure used by the female to coat eggs with particles of ground substrate (e.g., sand) prior to in-flight oviposition near potential hosts (Yeates and Greathead, 1997) to protect them from desiccation. Not unexpectedly then, much of the diversity of the Bombyliidae is found in xeric or semi-xeric environments, a situation that may bias the fossil record of the clade as the vast majority of all insect fossils are preserved either in amber from rather sylvan habitats or as compression/impression fossils from lacustrine environments.

The fossil record of the Bombyliidae s. str. is restricted to the Cenozoic; the oldest fossil, Paleolomatia menatensis, is from the sediments of a Paleocene maar near Menat, France (Nel, 2008). The complete absence of a fossil record for bombyliids in the Cretaceous has led to the conclusion that this clade originated and underwent a very rapid radiation in the early Cenozoic (Grimaldi, 1999). The vast majority of extant bombyliids (about $90 \%$ of all genera) belong to the "sandchamber clade", which consists of nine derived subfamilies. The oldest fossil evidence of an actual sand chamber is in Glaesamictus hafniensis (Cythereinae) in which the insect and an exerted sand chamber are preserved in Baltic amber (Hennig, 1966). The oldest members of this clade, $P$. menatensis (56 mya from Vincent et al., 1977 based on K-Ar dating; however, an age of 60-61 mya based on the presence of Plesiadapsis insignis is given in the supplementary online material in Wappler et al., 2009) and Comptosia pria (47 mya), both from the sand-chamber clade subfamily Lomatiinae, suggest a Cretaceous origin of the non-mythicomyiid Bombyliidae (Nel, 2008; Wedmann and Yeates, 2008).
By far the most diverse of the more derived subfamilies is Anthracinae, which contains nearly half of all bombyliid species and three of the four most speciose genera in the family. Relative to the rest of the bombyliids, however, the Anthracinae are poorly represented in the fossil record with only eight fossil species described (Evenhuis, 1994, 2013; Wedmann and Yeates, 2008). Of the 23 fossil bee flies listed in the Florissant database, only two are anthracines (Meyer, 2002). The Anthracinae, with its unique origin of $\mathrm{R}_{2+3}$ at a right angle to Rs, have been positioned as one of the most derived of the bombyliids (Yeates, 1994). Recent molecular phylogenetic studies, however, have suggested that the subfamilies Lordotinae (sensu Yeates, 1994) and the morphologically distinct Toxophorinae, both of which lack a sand chamber, are more derived than the anthracines (Trautwein et al., 2011).

In this study, Eoanomala melas Greenwalt and Evenhuis gen. and sp. nov. is described from the Middle Eocene oil shales of the Kishenehn Formation. Eoanomala melas contains a number of character states that are not found together in any one extant genus and, although placed in the tribe Villini, it does not appear to be closely related to the extant constituents of that clade. As the oldest fossil anthracine described, E. melas, along with the more derived toxophorine Paradolichomyia eocenica (Nel and Ploëg, 2004), again argue for a much earlier origin of these derived clades of Bombyliidae than the Cenozoic.

In addition, Anthrax succini, the first fossil specimen of the genus Anthrax is described from Dominican amber. The previously described Anthrax dentoni (Lewis, 1969), based on a partial wing from a $13+/-0.5$ mya locality within the Latah Formation (Gray and Kittleman, 1967), was reexamined. Anthrax dentoni could belong to any one of a large number of the genera of Anthracinae, including Anthrax, but given the paucity of morphological data available, it is assigned to Anthracinae incertae sedis.

\section{MATERIAL AND METHODS}

The three specimens described in this study are USNM 595155, a piece of oil shale from the Kishenehn Formation in Montana, USA, that contains the fossil Eoanomala melas, USNM 508762, a piece of amber from the Dominican republic that contains the fossil Anthrax succini, and UCM 28427, a piece of shale from the Latah Formation in Washington, USA, that contains the fossil Anthrax dentoni (Lewis, 1969). 


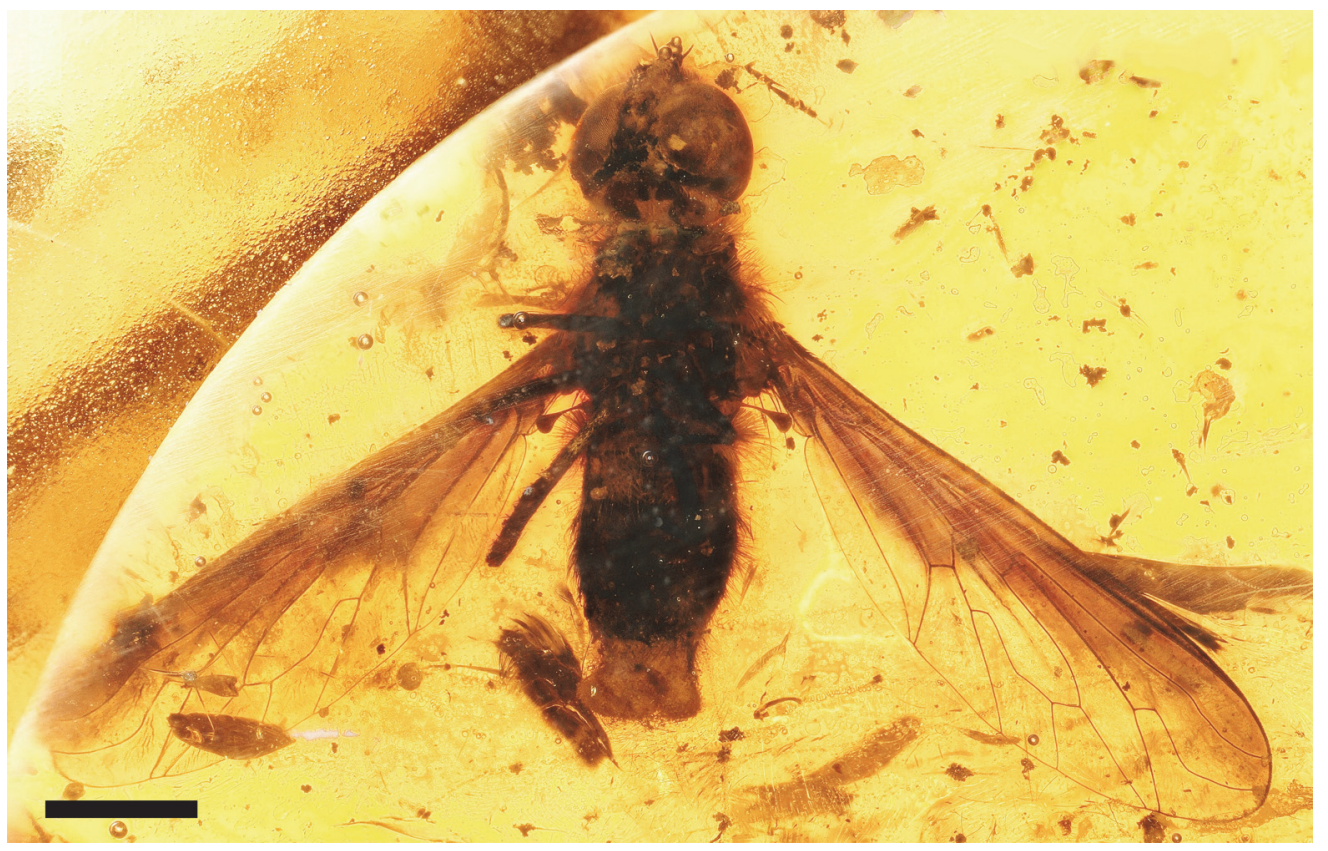

FIGURE 1. Anthrax succini sp. nov., USNM \# 508762. Scale bar equals $2 \mathrm{~mm}$.

In order to more clearly observe the inclusions in Specimen USNM 508762, the large $(5 \times 5 \times 2.5$ $\mathrm{cm})$ piece of amber was placed in a silicon mold and covered with EPO-TEK 301 epoxy resin (Epoxy Technology, Billerica, MA), which was then degassed under vacuum ( $\sim 40$ torr for 5 minutes). The resin was cured for 48 hours at $2^{\circ} \mathrm{C}$ to prevent overheating. The specimen was then cut with a Felker tile saw equipped with a Raytech 6-inch Red Blazer diamond blade with a kerf of 0.012-0.015 inches. The viewing facet was ground wet on 320 , 600 , and 1200 grit silicon carbide sandpaper. Polishing of the viewing facet was accomplished using a Leco SS-1000 Spectrum System Grinder Polisher equipped with an 8-inch Buehler Microcloth Polishing Cloth (No. 40-7218) and tin oxide polishing compound.

Specimen USNM 595155 was collected at the Dakin site on the Middle Fork of the Flathead River near Pinnacle, Montana in 2014 in accordance with USFS Authorization HUN281. The specimen was photographed with an Olympus SZX12 microscope equipped with a Q-Color5 Olympus camera. Image-Pro Plus 7.0 software (Media Cybernetics, Inc., Bethesda, MD) was used to capture and record the images. The specimen was immersed in 95\% ethanol for examination and photography. Specimens USNM 508762 and UCM 28427 were photographed with an Olympus DSX 100 microscope. All measurements are in millimeters $(\mathrm{mm})$ unless otherwise indicated. The radial loop index
(RLI), a measure of the relative depth of the apical loop of $R_{2+3}$, was determined as specified by Yeates (1991).

Abbreviations used herein are UCM (University of Colorado Museum of Natural History) and USNM (United States National Museum/National Museum of Natural History).

\section{SYSTEMATIC PALEONTOLOGY}

Order Diptera Linnaeus, 1758

Family Bombyliidae Latreille, 1802

Subfamily Anthracinae Latreille, 1802 Anthrax Scopoli, 1763

Type species. Musca morio Linnaeus 1758 [misidentification, = Musca anthrax Schrank, 1781], by monotypy

Anthrax succini Greenwalt and Evenhuis, new
species

(Figures 1-3)

zoobank.org/C6E7C426-EF8C-4D6A-AF6F-7A79BE9996BF

Etymology. The specific epithet derives from the Latin succinum meaning amber.

Holotype. USNM 508762; deposited in the Department of Paleobiology, National Museum of Natural History (NMNH), Smithsonian Institution, Washington, District of Columbia.

Type Horizon. Dominican amber, Miocene.

Type Locality. NMNH's Brodzinsky Lopez-Pena collection of Dominican amber. 


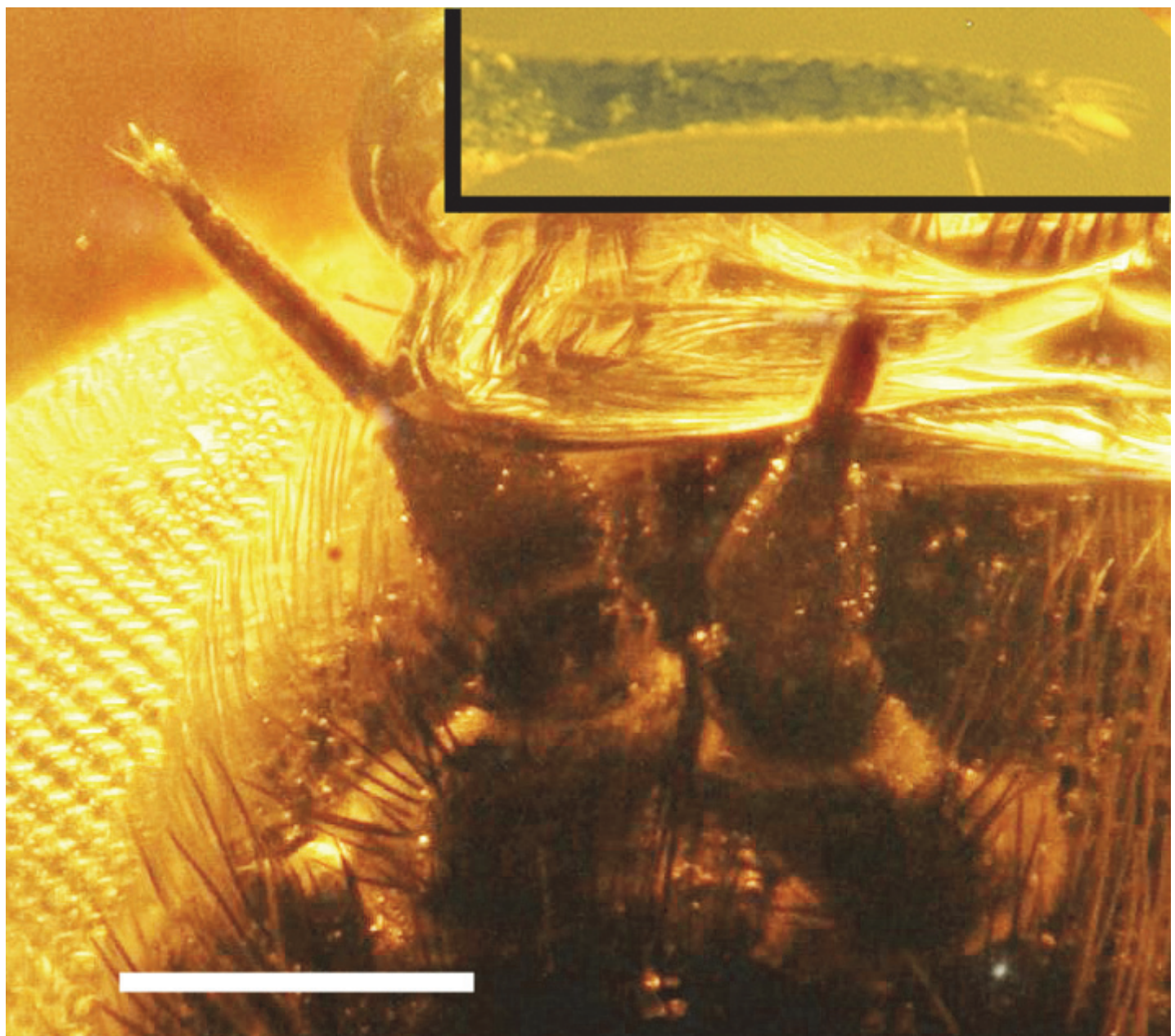

FIGURE 2. Antennae of Anthrax succini sp. nov., USNM \# 508762. Inset = magnified image of the stylet of the right antenna. Scale bar equals $250 \mu \mathrm{m}$.

Differential Diagnosis. In the key of Marston (1970), this specimen keys to the cephus group based on the solid pigmentation of its wings and the presence of facial setae extending almost to the antennae. The lack of cross-veins in cells $m_{2}$ and $r_{2+3}$, alula with a straight posterior margin, cell cup more than half pigmented, pigment in cell $r_{1}$ extending to wing apex, and middle femur with postmedial bristles anteriorly, keys this species to Anthrax delicatulus Walker, 1849. Both the female and male of $A$. delicatulus differ from related species in having postmedial bristles anteriorly on the middle femur. Females of $A$. delicatulus have been reported from Jamaica while a male has been reported from the Dominican Republic (Marston, 1970). Anthrax succini differs from the female of $A$. delicatulus in the form of veins $R_{4}$ and $M_{1}$, the relative positions of the distal portions of $A_{1}$ and $\mathrm{CuA}_{2}$ and the length of the styliform portion of the first flagellomere relative to that of the second flagellomere.

Description. Female. Lengths: Body (base of scape to end of the extended sand chamber at the terminus of the abdomen): $8.45 \mathrm{~mm}$ (Figure 1); wing (edge of thorax to apex): $9.37 \mathrm{~mm}$ with a maximum width of $2.54 \mathrm{~mm}$.

Head. Face, gena, front, vertex, and occiput all dark brown; eyes light brown with pronounced posterior indentation and short line bisecting the facets; vertex covered with short dark brown setae (Figure 1, 2). Face not tumid, upper half covered with dark brown setae to base of antennae, setae shorter medially and closer to scape, longer but thin laterally and longer and more stout anteriorly. All antennal segments dark brown, completely covered with short whitish microtrichia, especially pronounced at basal and apical perimeters of scape. Scape angled medially with dark setae basally (Figure 2). Pedicel with fewer and shorter setae. 


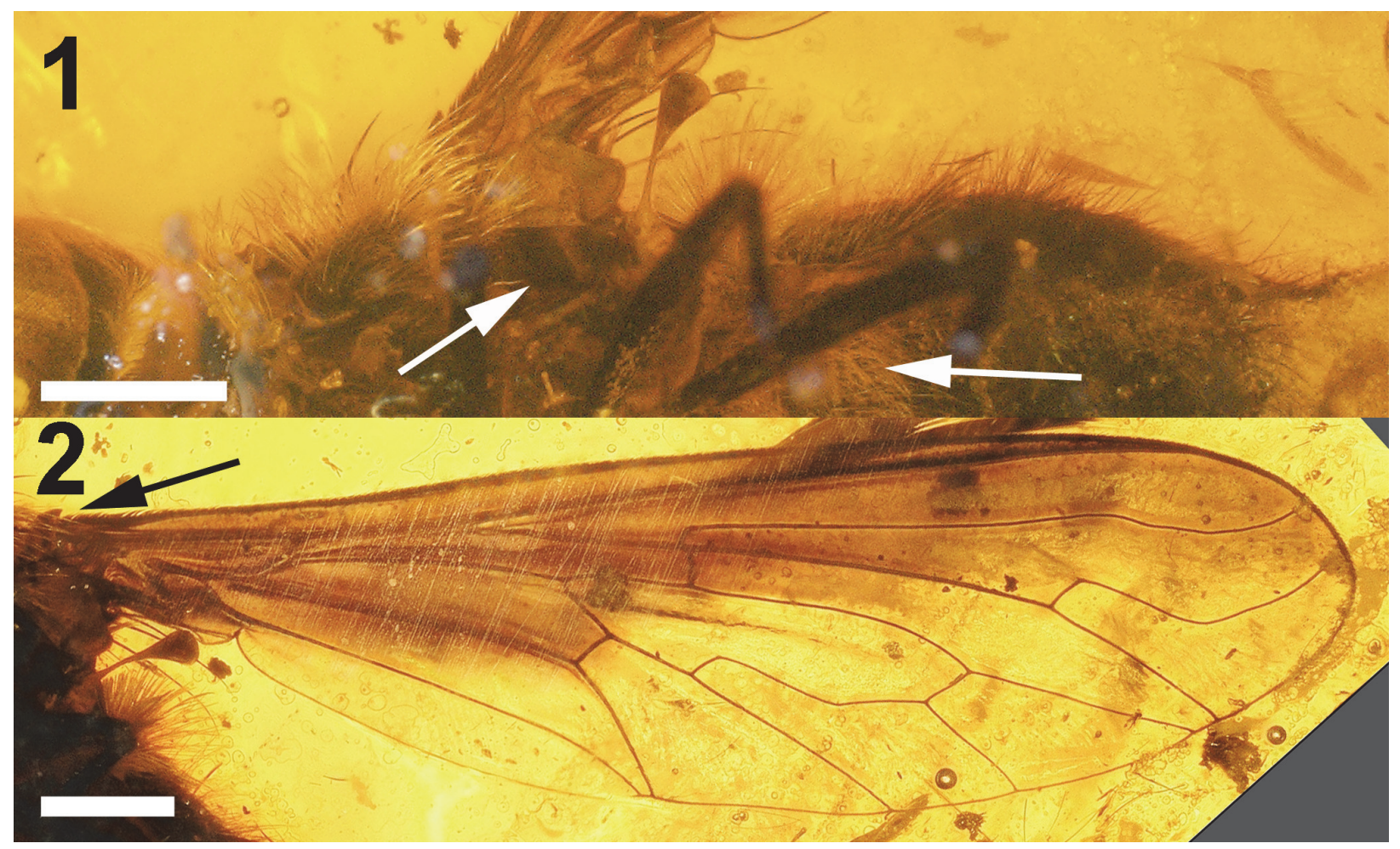

FIGURE 3. Anthrax succini sp. nov., USNM \# 508762. 1. Vestiture from ventral aspect of the specimen. Arrows, from left to right, denote the bare anepimeron and the band of white setae across the anterior sterna of the abdomen; 2 . Left wing. The arrow points to the basicosta. Scale bars in both figures equal $1 \mathrm{~mm}$.

First flagellomere onion shaped, subconical basally, with elongate subcylindrical apical portion, cylindrical portion equal in length to the subconical base; second flagellomere subcylindrical, approximately $1 / 4$ as long as the elongate apical portion of first flagellomere; style whitish; apex surrounded by several setae (Figure 2). Ocellar tubercle minute; posteroventral margin of occiput with fringe of short white setae. Mouthparts not present in specimen (not preserved).

Thorax. Anterior edge of mesonotum and pleura with collar of long white setae that surround the occiput of the head (Figure 3); mesonotum with very long stout black macrochaetae laterally, two anterior and three posterior of wing base; mesonotum and scutellum dark brown, sparsely covered with short fine brown setae dorsally, with long white setae laterally; all lateral and medial sclerites dark brown; mesosternum bare except for short white setae along its posterior edge; mesopleuron with white setae over its posterior $2 / 3$ with the setae becoming longer more posteriorly with a single long black macroseta originating posterior to anepisternal suture; anepimeron, meron, laterotergite, and metepimeron bare. Halter slightly recurved, knob light brown, base with setae at anterior edge.
Legs.Procoxa with brown setae and sparse white scales, mesocoxa with black setae; meso and metafemora with basal white scales. Anterior side of mesofemora with three stout bristles posteromedially. Tibia (partially) and tarsi (completely) missing on all legs.

Wing (Figure 3). Hyaline except for brown pigmentation anteriorly and basally. Basicosta stout, triangular, slightly recurved posteriorly, ending in sharp point. Cells c, sc, $r_{1}, b m$, and bm and all of $r_{2+3}$ except for its posterior-most edge along $R_{4}$ pigmented, as well as basal half of cell $r_{5}$, anterobasal quarter of discal cell and basal half of cell cup; $r-m$ cross-vein at basal third of discal cell (cell $1 m_{2}$ ) and just distal of origin of $R_{2+3}$; veins in radial field without recurrent spurs. $M_{1}$ and $M_{2}$ terminate at wing margin; length of contact between cells $1 \mathrm{~m}_{2}$ and cua ${ }_{1}$ twice that of base of cua ${ }_{1}$; cell cup present, terminating just over a third of the way along $\mathrm{CuA}_{2} ; \mathrm{A}_{1}$ terminating at margin basal of $\mathrm{CuA}_{2}$; anal lobe as wide as cup, margin not reduced. Alula small, slightly convex distally, but recurved and narrow and straight basally.

Abdomen. Tergites covered with short black setae except tergite 2 covered by short white setae form- 

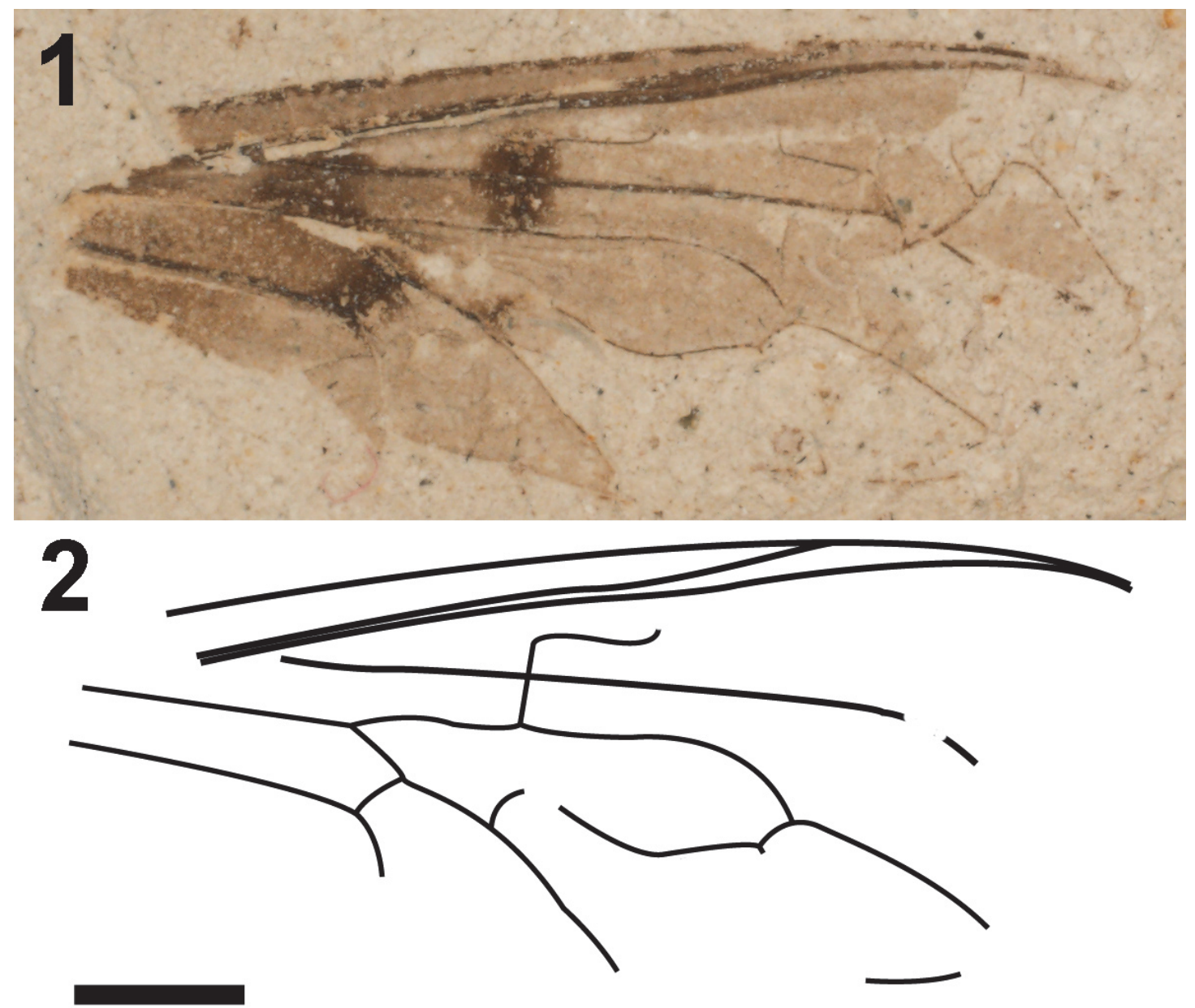

FIGURE 4. Anthrax dentoni Lewis, 1969, UCM \# 28427. 1. Photograph of the fossil. 2. Line drawing of venation. Scale bar equals $1 \mathrm{~mm}$.

ing a conspicuous transverse band; tergite 2 with dense patch of long, stout white setae laterally. Medial portion of sternites 1-3 covered with fine short white setae which are also found laterally. Short white setae continue, albeit less thickly, posteriorly along the lateral edges of sternites; posterior sternites covered with longer fine black setae medially and laterally. Apex of abdomen with exserted sand chamber filled with fine sand grains. Type material. Holotype female (Figure 1): Dominican amber, USNM \# 508762. Synclusions include a single nematoceran fly, a very small $(<1 \mathrm{~mm})$ adult psocopteran and what appears to be a second specimen of $A$. succini. However, the entire head of the latter insect is missing and most of the remaining morphological details are obscured due to opaque amber.

Anthrax dentoni Lewis, 1969, reassigned

(Figure 4)
Holotype. UCM \# 28427; housed in the University of Colorado Paleontology Collection, Boulder, Colorado.

Type Horizon. Latah Formation, Miocene.

Type Locality. Deep Creek Canyon, Spokane, Washington

Remarks. Collected from the Early to Middle Miocene Latah Formation in northwestern Idaho, Anthrax dentoni was described by Lewis (1969) based on a single incomplete wing fragment. Although the Latah Formation was laid down over a period of approximately 9 million years (21.312.1 mya), Lewis (1969) reported that this fossil was collected from the Deep Creek Canyon locality northwest of Spokane, Washington. K-Ar dating of basalt immediately above the fossiliferous sedimentary rocks at Deep Creek Canyon has provided a date of $13+/-0.5$ mya (Gray and Kittleman, 1967). Assignment of the fossil to the genus Anthrax was based on basal pigmentation, the ori- 


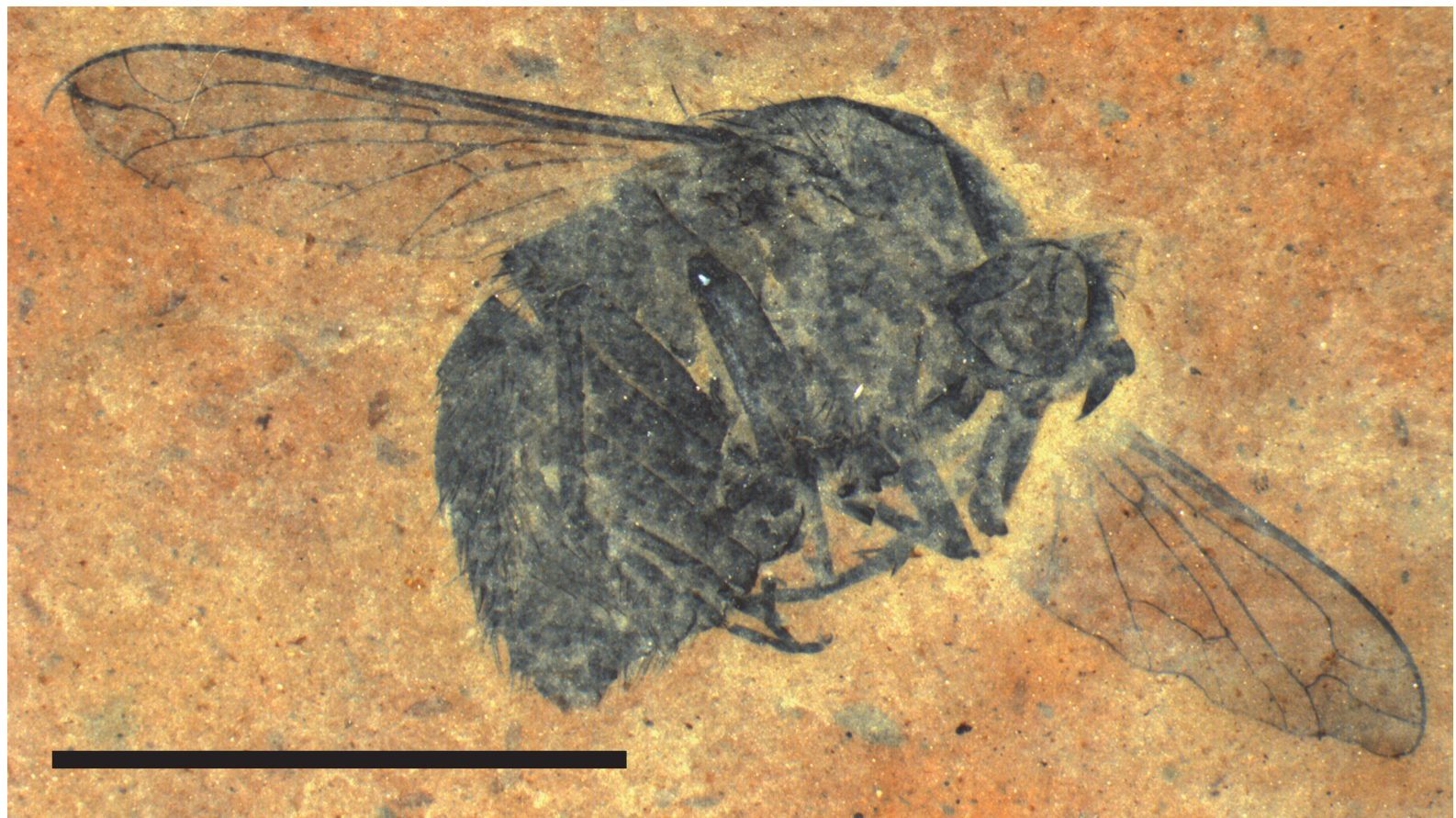

FIGURE 5. Eoanomala melas gen. and sp. nov. USNM \# 595155. Scale bar equals $5 \mathrm{~mm}$.

gin of $R_{2+3}$ at right a right angle to $R s$, the shape of the second posterior cell, the presence of adventitious veins, and the "stub of the vein above the r-m cross-vein." Upon re-examination, this fossil consists of the partial venation of two wings, one superimposed on the other (Figure 4). The venation pattern of the major wing fragment is presented in Figure 4. Lewis's "Vein $\mathrm{R}_{1}$ incomplete, forming two separate adventitious veins rather than one continuous vein" evidently refers to vein $R_{2+3}$, not $R_{1}$; the two separate adventitious veins are actually veins from two different wings. The upturned end of the preserved portion of $\mathrm{R}_{2+3}$ would be unique within Bombyliidae; however, the specimen is very 3-dimensional, and redirection of the vein appears to be an artifact of the insect's burial in relatively thick clastic sediments. The grain size of the tuffaceous matrix of this specimen is commonly several microns in diameter with crystals of mica as large as $65 \mu$ in length. The origin of $R_{2+3}$ is at a right angle to $R s$ and is in-line with $r-m$, identifying this specimen as a species in the subfamily Anthracinae. Given the essential absence of vein $M_{2}$, it is impossible to discern the shape of cell $m_{1}$. There is a very tiny portion of sclerotized vein basal to the origin of $\mathrm{M}_{2}$ that may be a remnant of a spur vein, but its connection to $\mathrm{m}-\mathrm{cu}$ is not preserved. Vein $A_{1}$ is also not preserved and the specific veins that make up what appears to be the apical venation of a second wing cannot be identified. The pigmentation of the anterobasal half of the wing, the particularly heavy areas of pigmentation at $\mathrm{r}-\mathrm{m}$ (Figure 4 ), the base of the 4 th posterior cell, the origins of Rs and $\mathrm{R}_{2+3}$ and, to a lesser degree, the terminus of $\mathrm{m}-\mathrm{cu}$, are found in a number of bombyliid subfamilies. It is impossible, however, to assign this specimen to a specific tribe, let alone genus, within Anthracinae. We, therefore, assign Anthrax dentoni to Anthracinae incertae sedis.

Eoanomala Greenwalt and Evenhuis, new genus zoobank.org/A120C15F-AB19-4C3F-94C6-1BA7BFEB5371

Differential diagnosis. Small stout fly, entirely black with wings equal to body length (wing length/ body length ratio $=0.99$ ). Vein $R_{2+3}$ originating at right angle from Rs and just basal to r-m crossvein. Head round, not distinctly tumid, vertex covered with numerous long setae. Eyes large with distinct lateral indentation on posterior margin. Antenna with large scape, large conical first flagellomere, short second flagellomere and terminal style. Proboscis large, equal to length of head, with a fleshy labellum. Abdomen covered with numerous long stout setae.

\section{Eoanomala melas Greenwalt and Evenhuis, new species}

(Figures 5-7)

zoobank.org/9BB961F7-A72B-4285-B22F-6795B473C099 


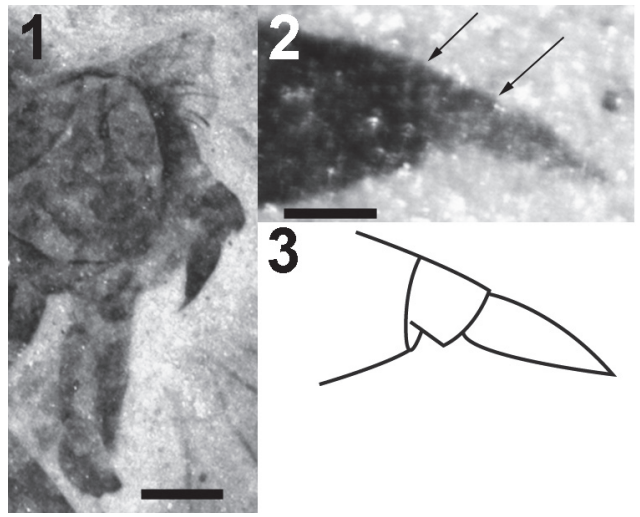

FIGURE 6. Eoanomala melas gen. and sp. nov. USNM \# 595155. 1. Head and proboscis; 2. Photograph of second flagellomere and terminal style; 3 . Stylized line drawing of second flagellomere and style. Scale bars equal $0.5 \mathrm{~mm}$ (1) and $0.05 \mathrm{~mm}(2)$.

Differential Diagnosis. As for genus.

Etymology. The generic epithet derives from the Greek eos meaning dawn or early and anomalos meaning deviating from normal. The specific epi- thet derives from the Greek melas meaning black, dark.

Holotype. USNM \# 595155. [sex undetermined] (Figure 5); deposited in the Department of Paleobiology, National Museum of Natural History (NMNH), Smithsonian Institution, Washington, District of Columbia.

Type Horizon. Kishenehn Formation, middle Eocene (Lutetian).

Type Locality. Park site, Middle Fork of the Flathead River, near Pinnacle, Montana.

Description. Sex undetermined. Body length (base of scape to end of the terminus of the abdomen) $6.09 \mathrm{~mm}$ (Figure 5).

Head. Black. Eyes black, with pronounced but gradually curved posterior indentation laterally, short line bisecting the facets, if present, not visible; eyes slightly higher than long. Face not tumid, vertex covered with 15-20 black setae (Figure 6.1). Antennae black, large (Figure 6). Scape large, as wide as long. Pedicel wider than long. First flagellomere conical, second flagellomere subquadrate, about $1 / 12$ the length of the first and with a terminal style more than twice the length of

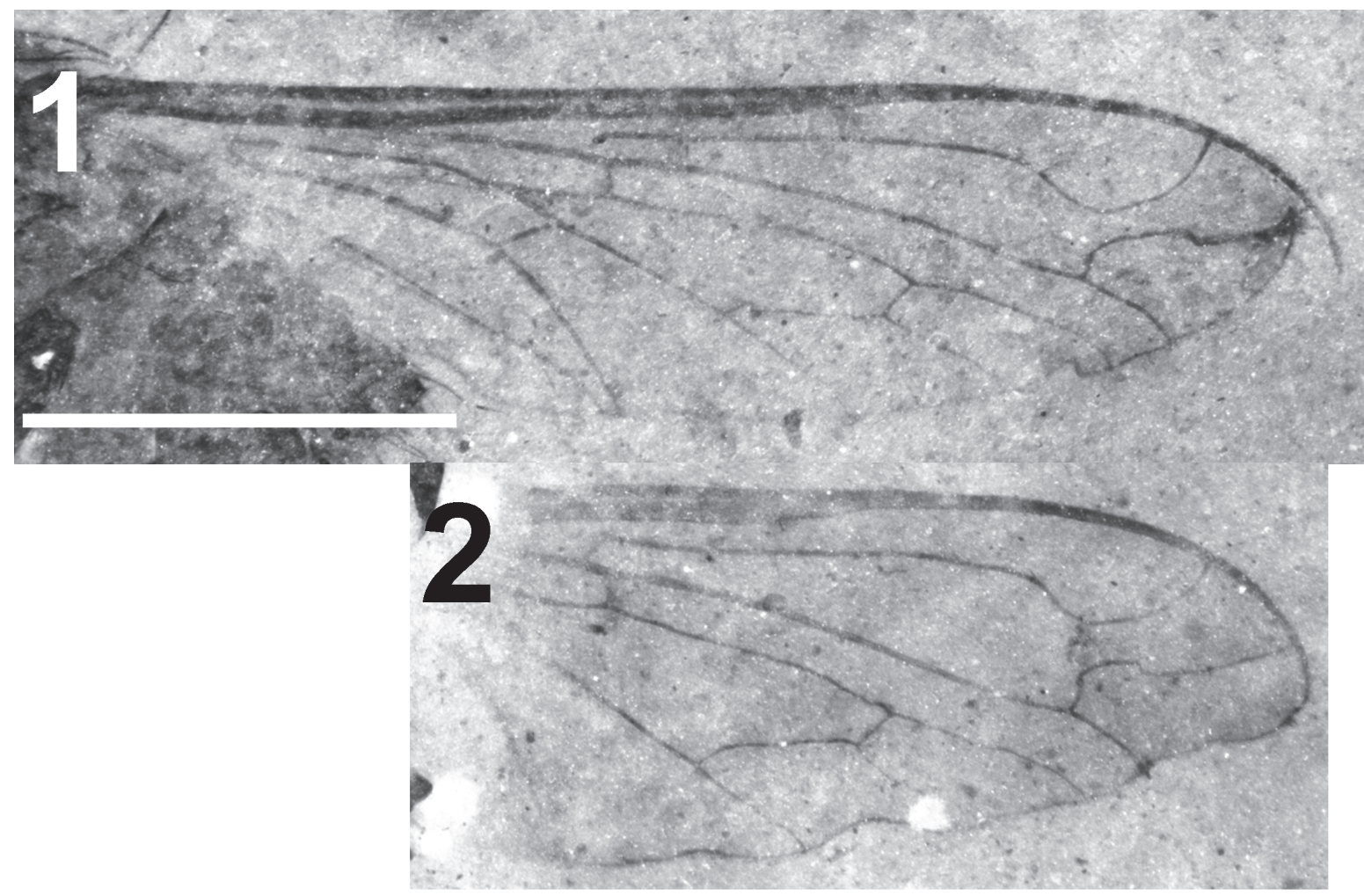

FIGURE 7. Wings of Eoanomala melas gen. and sp. nov. USNM \# 595155. 1. Right wing. Note that this wing has been damaged and consequently, its maximum width and the shape of $R_{4}$ have been affected; 2 . Left wing (basal portion not visible in the fossil). Scale bar for both micrographs equals $2 \mathrm{~mm}$. 
the second flagellomere. Proboscis extended beyond oral margin, nearly as long as head.

Thorax. Black. Several long, stout bristles just above wing base and long thinner setae anterior to wing base.

Legs. Black. Long bristles at base of meso and procoxae. Posterolateral surface of metafemur with row of about 10 short bristles. Junctions between meta and mesofemur and tibia and junctions between individual metatarsal segments characterized by stout spines.

Wing. Hyaline (Figure 7), $6.04 \mathrm{~mm}$ in length (left wing) and $1.72 \mathrm{~mm}$ maximum width; basicosta covered with short setae; r-m cross vein at proximal $1 /$ 4 of discal cell (cell $1 \mathrm{~m}_{2}$ ) and distal to origin of $R_{2+3}$ by a distance just less than the length of $r-m$; veins in radial field without recurrent spurs. $\mathrm{RLI}$ of $\mathrm{R}_{2+3}=$ 0.115 . Vein $R_{4}$ with loop in apical third, shape of loop unique in that, after its initial turn towards the wing's apical margin, it turns posteriorly at a right angle before turning again to resume its course to the wing margin. $M_{1}$ and $M_{2}$ terminate at wing margin; length of contact between cells $1 \mathrm{~m}_{2}$ and cua ${ }_{1}$ 3.5 times that of the base of cua ${ }_{1}$; CuP present; $A_{1}$ terminating at margin basal of $\mathrm{CuA}_{2}$; Alula not visible.

Abdomen. Black, $3.43 \mathrm{~mm}$ long, $2.7 \mathrm{~mm}$ wide. Entire dorsum and posterior third of venter covered with long setae. Terminus of the abdomen slightly protuberant, slightly concave at apex.

\section{DISCUSSION}

The only species from the New World similar to Anthrax succini is the extant Anthrax delicatulus Walker, which is known from Jamaica and the Dominican Republic. Anthrax succini differs from the female of $A$. delicatulus in the degree of wing pigmentation. Specifically, pigmentation in A. delicatulus extends more distally in the cup cell - past the first sector of the $\mathrm{CuA}_{1}$ vein and the first posterior cell - where it contacts vein $M_{1}$, and extends past the origin of $R_{4}$ and into cell $r_{4}$. Additionally, in $A$. delicatulus, there is a distinct hyaline region between the basal and distal most pigmentation of cell $r_{2+3}$ that is, for the most part, absent in A. succini. The venation differs between the two species in a number of aspects. In $A$. delicatulus, $\mathrm{R}_{4}$ has a long recurrent spur, whereas in $A$. succini, the spurs are absent or minute. $\mathrm{R}_{2+3}$ originates basal to the $r-m$ cross vein in $A$. succini, but is in-line in $A$. delicatulus. The curve of the middle portion of $\mathrm{R}_{4}$ is $\mathrm{C}$-shaped in $A$. succini rather than $\mathrm{S}$-shaped in $A$. delicatulus. In addition, the styliform portion of first flagellomere of $A$. succini is four times as long as the second, whereas in $A$. delicatulus, as figured by Marston (figure 108, 1970), the styliform portion (Marston's "style") of the first flagellomere is only 1.5 times as long as the second. Also, the mesofemur of $A$. delicatulus has a single large anterior postmedial bristle whereas $A$. succini has three. Only two specimens of $A$. delicatulus are known (Marston, 1970), but the differences between the two are consistent and enough to warrant this amber specimen to be described as a new species.

Eoanomala melas appears to be an exoprosopine (the first antennal segment is characteristic of a number of exoprosopine genera), but the very short wing length compared to the body length is quite different from all exoprosopines. The proboscis is also quite different; all exoprosopine taxa have a much shorter proboscis in relation to the head. If the proboscis is long (i.e., extending well beyond the oral margin), then it is tubular and thinner. This fossil specimen instead has a fleshy proboscis which does appear to be extended. The body is also short and fat (a trait seen in bombyliines). There are a few African exoprosopine genera that have short bodies, but the wings are much longer. There are also some fat-bodied bombyliids (because they retain fat deposits) that are similar in body appearance to this fossil specimen, but they all have reduced mouthparts.

Eoanomala melas keys to the tribe Villini based on the absence of an interradial cross-vein between $R_{2+3}$ and $R_{4}$. A definitive tribal assignment to either Villini or Exoprosopini is impossible, however, due to our inability to determine the presence or absence of pulvilli (Greathead and Evenhuis, 2001). Moreover, while the submarginal cell number is a good character state for discriminating between most extant genera, the evolutionary significance of the supernumerary cross-veins in the fossil fauna is not understood well enough to determine if it is a good separating character between the two tribes.

\section{ACKNOWLEDGMENTS}

We thank C. Labandeira, F. Marsh, and S. Whittaker of the NMNH for administrative and technical support and A. Rulis for his assistance with locating the amber specimen USNM 508762. We thank D. Smith and T. Karim of the University of Colorado, Boulder for the loan of specimen UCM 28427. This is contribution number 330 of the Evolution of Terrestrial Ecosystems Consortium of the USNM. 


\section{REFERENCES}

Evenhuis, N.L. 1994. Catalogue of the fossil flies of the world (Insecta: Diptera). Backhuys Publishers, Leiden. $600 \mathrm{pp}$.

Evenhuis, N.L. 2013. A new species of Hemipenthes LOEW (Diptera: Bombyliidae: Anthracinae) from Miocene Dominican amber. Polish Journal of Entomology/Polskie Pismo Entomologiczne, 82(4):281-286.

Evenhuis, N.L. and D.J. Greathead. 2003. World catalog of bee flies (Diptera: Bombyliidae) web site. [http:// hbs.bishopmuseum.org/bombcat/].

Gray, J. and Kittleman, L.R. 1967. Geochronology of the Columbia River Basalt and associated floras of eastern Washington and western Idaho. American Journal of Science, 265:257-291.

Greathead, D. J. and Evenhuis, N. L. 2001. Annotated keys to the genera of African Bombylioidea (Diptera: Bombyliidae; Mythicomyiidae). African Invertebrates, 42: $105-224$.

Grimaldi, D. 1999. The co-radiations of pollinating insects and angiosperms in the Cretaceous. Annals of the Missouri Botanical Garden, 86:373-406.

Hennig, W. 1966. Bombyliidae im Kopal und im Baltischen Bernstein (Diptera: Brachycera). Stuttgarter Beiträge zur Naturkunde, 166:1-20.

Latreille, P. A. 1802. Histoire naturelle, générale et particulière, des crustacés et des insectes. Tome troisième. Familles naturelles des genres. Ouvrage faisant suite à l'histoire naturelle générale et particulière, composée par Leclerc de Buffon, et rédigée par C.S. Sonnini, membre de plusieurs sociétés savantes. Dufart, Paris. xii +13-467 + 1 pp.

Linnaeus, C. 1758. Systema naturae per regna tria naturae, secundum classes, ordines, genera, species, cum caracteribus, differentiis, synonymis, locis. Tomus I. Editio decima, reformata. L. Salvii, Holmiae. $824 \mathrm{pp}$.

Lewis, S.E. 1969. Fossil insects of the Latah Formation (Miocene) of Eastern Washington and Northern Idaho. Northwest Science, 43(3):99-115.

Marston, N. 1970. Revision of New World Species of Anthrax (Diptera: Bombyliidae), Other Than the Anthrax albofasciatus Group. Smithsonian Contributions to Zoology, 43:1-148.

Meyer, H.W. 2002. Fossil Bombyliidae occurrence data, accessed 10/30/2014. Florissant Fossil Beds National Monument Database. planning.nps.gov/flfo/

Nel, A. 2008. The oldest bee fly in the French Paleocene (Diptera: Bombyliidae). Comptes Rendus Palevol, 7:401-405.
Nel, A. and de Ploeëg, G. 2004. New fossil bee flies (Diptera: Bombylioidea) in the Lowermost Eocene amber of the Paris Basin. Geologica Acta, 2(1):57-65.

Pape, T., Blagoderov, V., and Mostovski, M.B. 2011. Order DIPTERA Linnaeus, 1758. In Zhang, Z.-Q. (ed.), Animal biodiversity: An outline of higher-level classification and survey of taxonomic richness. Zootaxa, 3148:222-229.

Scopoli, J.A. 1763. Entomologia Carniolica exhibens insects Carnioliae indigena et distributa in ordines, genera, species, varietates. Methodo Linneana. Vindobonae, Trattner.

Schrank, F. 1781. Enumeratio insectorum austriae indigenorum. (Agustae Vindelicorum: Klett.)

Trautwein, M.D., Wiegmann, B.M., and Yeates, D.K. 2011. Overcoming the effects of rogue taxa: Evolutionary relationships of the bee flies. PLOS Currents Tree of Life, 3:1-20 (RRN1233). doi: 10.1371/currents.RRN1233.

Vincent, P.M., Aubert, M., Boivin, P., Cantagrel, J.M., and Lenat, F. 1977. Decouverte d'un volcanisme Paleocene en Auvergne; les maars de Menat et leurs annexes, etude geologique et geophysique. Bulletin de la Société Géologique de France, 5:1057-1070.

Walker, F. 1849. List of the Specimens of Dipterous Insects in the Collection of the British Museum. 2:231-484. London: British Museum (Natural History).

Wappler, T., Currano, E.D., Wilf, P., Rust, J., and Labandeira, C.C. 2009. No post-Cretaceous ecosystem depression in European forests? Rich insect-feeding damage on diverse middle Palaeocene plants, Menat, France. Proceedings of the Royal Society of London B: Biological Sciences, 276:4271-4277.

Wedmann, S. and Yeates, D.K. 2008. Eocene records of bee flies (Insecta, Diptera, Bombyliidae, Comptosia): Their palaeobiogeographic implications and remarks on the evolutionary history of bombyliids. Palaeontology, 51(1):231-240.

Yeates, D. 1991. Revision of the Australian bee fly genus Comptosia (Diptera: Bombyliidae). Invertebrate Taxonomy, 5:1023-1178.

Yeates, D.K. 1994. The cladistics and classification of the Bombyliidae (Diptera: Asiloidea). Bulletin of the American Museum of Natural History, 219:1-191.

Yeates, D.K. and Greathead, D.J. 1997. The evolutionary pattern of host use in the Bombyliidae (Diptera): a diverse family of parasitoid flies. Biological Journal of the Linnean Society, 60:149-85. 